\title{
ХАРАКТЕРИСТИКА ФИТОПАТОГЕННОЙ НАГРУЗКИ СЕМЯН ОЗИМОЙ ПШЕНИЦЫ УСТОЙЧИВОГО К БОЛЕЗНЯМ СОРТА КУЯЛЬНИК ПРИ ПОМОЩИ МОЛЕКУЛЯРНО-ГЕНЕТИЧЕСКИХ МЕТОДОВ
}

\author{
Кузнецова И.И., Белоусова Г.Г. \\ Институт генетики, физиологии и защиты растений Республики Молдова \\ 2.Кишинев, Республика Молдова E-mail:mamakuza@mail.ru
}

\begin{abstract}
The aim of this work was to test the seeds of the Kuyalnik variety (harvest of 2019) for the presence of pathogens of the genera Fusarium, Myrothecium, Alternaria, Penicillium, and Aspergillus by molecular genetic methods (PCR, nested-PCR). The use of species-specific primers for these pathogens allowed to detect 6 species of Fusarium (F. verticillioides, F. avenaceum, F. oxysporum, F. equiseti, F. sporotrichioides, F. incarnatum) in the seeds of the disease-resistant variety of winter wheat. It was found that the seeds of this variety of winter wheat also contained a large amount of Alternaria alternata, and a trace amount of Penicillium spp. Phytopathogens of the Myrothecium spp. genus and of the Aspergillus parasiticus were not identified in the DNA isolated from the seeds of the winter wheat variety Kuyalnik. The presence of such a diversity of fungal pathogens in the seeds of the resistant winter wheat variety Kuyalnik requires treatment of seeds with fungicides.
\end{abstract} pathogens

Keywords: winter wheat, seeds testing, molecular genetic methods, PCR, nested-PCR, fungal

\section{Введение}

Озимая пшеница является одной из важнейших продовольственных культур не только в Республике Молдова, но и в мире, поэтому особое внимание должно уделяться подбору устойчивых к болезням сортов озимой пшеницы как для воспроизводства, так и для гибридизации, агротехническим приемам возделывания данной культуры с целью повышения ее урожайности, адекватным фитосанитарным мерам по сохранению ее продуктивности в посевах и качества зерна. При возделывании зерновых культур грибы рода Fusarium, вызывающие корневые гнили и фузариозные заболевания колоса, наносят колоссальный урон: сокращается число колосков в колосе, уменьшается число зерен в нем, масса зерна, масса 1000 зерен, сильно страдает качество зерна, заражаются зернохранилища и почва. Подавляющее большинство видов Fusarium - активные продуценты микотоксинов (дезоксиниваленол, Т-2 токсин, зеараленон, фумонизин и т. д.), содержание этих веществ в продуктах питания и сырье строго регламентировано надзорными органами. В настоящее время доказано губительное влияние грибков рода Myrothecium на качество семян пшеницы при неправильном хранении в зернохранилищах(Николаева С., Маржина Л., Николаев А., 2010). Зараженное зерно, попадая в почву, особенно в условиях достаточной увлажненности, вызывает стремительное распространение данного грибка. Не менее актуальной проблемой является поражение зерна озимой пшеницы грибками родов Alternaria, Penicillium и Aspergillus. Мировые потери от грибных болезней составляют до 10\% валового сбора урожая сельскохозяйственных культур. Сорт Куяльник украинской селекции (Национальный центр семеноведения и сортоизучения НААН Украины)- высокоурожайный сорт озимой пшеницы ( до 10 т/га) с высокой устойчивостью к поражению головней, септориозом, желтой ржавчиной, среднеустойчивый к фузариозам колоса ( 4 балла из 7). Селекционеры 
нашего института и всей Молдовы используют сорт Куяльник в качестве стандарта качества зерна и урожайности в различных условиях вегетации с 2005 года, кроме того с использованием этого сорта создано много высокоустойчивых гибридов озимой пшеницы. Цель данной работы - протестировать с помощью молекулярно-генетических методов (ПЦР, nested-ПЦР) семена сорта Куяльник урожая 2019 года на наличие в них патогенов родов Fusarium, Myrothecium, Alternaria, Penicillium и Aspergillus.

\section{Материалы и методы}

Объектом исследования были семена озимой пшеницы сорта Куяльник урожая 2019 года, собранные на опытных участках Института генетики, физиологии и защиты растений Республики Молдова.

Выделение ДНК: суммарная ДНК была выделена из 1 грамма (24 зерновки) семян озимой пшеницы сорта Куяльник методом ISO (21571:2005), которая затем использовалась для ПЦР анализа. Для навески отбирались выполненные визуально здоровые семена без каких-либо дефектов.

Праймеры 2 раунда, подобранные для идентификации фитопатогенов методом ПЦР

\begin{tabular}{|c|c|c|c|c|}
\hline Патоген & $\begin{array}{c}\text { Пара } \\
\text { праймеро } \\
\text { в }\end{array}$ & Последовательность $\left(5^{\prime} \rightarrow 3^{\prime}\right)$ & $\begin{array}{c}\text { Область } \\
\text { генома }\end{array}$ & $\begin{array}{c}\text { Амплико } \\
\text { н } \\
\text { (п.о.) }\end{array}$ \\
\hline \multirow{2}{*}{$\begin{array}{l}\text { Aspergillus } \\
\text { parasiticus }\end{array}$} & ap3 (F) & TTGTTCTGGGCGAAGCATCAT & \multirow{2}{*}{$\begin{array}{l}\text { Oxidoreducta } \\
\text { se }(\operatorname{ordA})\end{array}$} & \multirow[t]{2}{*}{940} \\
\hline & ap4 (R) & CCAAAGGCGAAGCAGGGT & & \\
\hline \multirow{2}{*}{$\begin{array}{l}\text { Alternaria } \\
\text { alternata }\end{array}$} & aa2 (F) & GGCGTCAGCAGAGGGAG & \multirow{2}{*}{$\begin{array}{l}\text { Glyceraldehy } \\
\text { de 3- } \\
\text { phosphate } \\
\text { dehydrogenas } \\
\text { e gene (GPD) }\end{array}$} & \multirow{2}{*}{289} \\
\hline & aa3 (R) & ACACCCATAACGAACATGGGG & & \\
\hline \multirow{2}{*}{$\begin{array}{l}\text { Penicillium } \\
\text { spp. }\end{array}$} & $\mathrm{p} 18 / 2(\mathrm{~F})$ & ACTCTGCCTGAAGATTGTCGT & \multirow{2}{*}{$\begin{array}{l}18 \mathrm{~S} \\
\text { ribosomal } \\
\text { RNA gene }\end{array}$} & \multirow[t]{2}{*}{249} \\
\hline & $\mathrm{p} 18 / 3(\mathrm{R})$ & CGGAATCGGAGGACGGG & & \\
\hline \multirow[t]{2}{*}{ Fusarium spp. } & $\mathrm{fc} 3(\mathrm{~F})$ & $\begin{array}{l}\text { CCATCGAGAAGTTCGAGAAGGT } \\
\mathrm{T}\end{array}$ & \multirow[t]{2}{*}{ TEF1 gene } & \multirow[t]{2}{*}{300} \\
\hline & fc4(R) & CCCAGGCGTACTTGAAGGAA & & \\
\hline \multirow{2}{*}{$\begin{array}{l}\text { F. } \\
\text { verticillioides }\end{array}$} & Fv2(F) & ATCGTAAACCCGGCCAAGAC & \multirow[t]{2}{*}{ TEF1 gene } & \multirow[t]{2}{*}{302} \\
\hline & fv $4(R)$ & GGAATGGGAGAGGGCAGAAAC & & \\
\hline \multirow[t]{2}{*}{ F. avenaceum } & fa3 $(F)$ & CGACTCGCTCCCTCATTCG & \multirow[t]{2}{*}{ TEF1 gene } & \multirow[t]{2}{*}{139} \\
\hline & fa4(R) & GTTTTGTGGGAACAGGGCAAG & & \\
\hline \multirow[t]{2}{*}{ F. oxysporum } & Fox $2(\mathrm{~F})$ & $\begin{array}{l}\text { GTCAACATACTGACATCGTTTC } \\
\text { ACA }\end{array}$ & \multirow[t]{2}{*}{ TEF1 gene } & \multirow[t]{2}{*}{328} \\
\hline & fox $4(\mathrm{R})$ & ACGTGACGACGCACTCATT & & \\
\hline F. equiseti & fqeqin $2(\mathrm{~F})$ & $\begin{array}{l}\text { TCCCCAGAATCAATACGCTAAC } \\
\text { C }\end{array}$ & $\begin{array}{l}\beta \text {-tubulin } \\
\text { gene }\end{array}$ & 104 \\
\hline
\end{tabular}




\begin{tabular}{|c|c|c|c|c|}
\hline & fqeqin3(R) & $\begin{array}{l}\text { TCACTGGGTAACAAGGTCGAAG } \\
\text { A }\end{array}$ & & \\
\hline \multirow{2}{*}{$\begin{array}{l}\text { F. } \\
\text { sporotrichioid } \\
\text { es }\end{array}$} & fqspte2 (F) & $\begin{array}{l}\text { CTCTCATACGACGACTCGACAA } \\
\text { G }\end{array}$ & \multirow[t]{2}{*}{ tef1 gene } & \multirow[t]{2}{*}{135} \\
\hline & $\begin{array}{l}\text { Fqspte3 } \\
\text { (R) }\end{array}$ & TGTGTGGGAAGGGCAAAAGC & & \\
\hline \multirow[t]{2}{*}{$\begin{array}{l}\text { Myrothecium } \\
\text { roridum }\end{array}$} & myr3 (F) & $\begin{array}{l}\text { TGTCTTTAGTGGTTTTCTCCTCT } \\
\text { GA }\end{array}$ & \multirow{2}{*}{$\begin{array}{l}\text { ITS-small } \\
\text { subunit } \\
\text { ribosomal } \\
\text { RNA gene }\end{array}$} & \multirow[t]{2}{*}{306} \\
\hline & myr4 (R) & GAGACCGCCACTGAATTTCG & & \\
\hline $\begin{array}{l}\text { Albifimbria } \\
\text { verrucaria }\end{array}$ & av3 (F) & GCTCAAGTCGCAACGAGATTC & $\begin{array}{l}\text { calmodulin } \\
\text { gene }\end{array}$ & 272 \\
\hline
\end{tabular}

Амплификация. Для анализа грибков рода Fusarium, Myrothecium,Alternaria, Penicillium и Aspergillus были проведены реакции nested-ПЦР со вложенной парой праймеров. В качестве сайтов-мишеней при выявлении видового разнообразия фузариума, определяемого в суммарной ДНК, использовались последовательности, указанные в таблице. Для определения видового разнообразия грибков семейства Myrothecium использовались последовательности ITS ДНК М. roridum и M. verrucaria (GenBank). В таблице содержится информация об используемых парах праймеров 2 раунда nested-ПЦР для определения видового разнообразия Fusarium spp. , Myrothecium spp., Penicillium spp., Aspergillus parasiticus и Alternaria alternata, также приведены размеры амплифицируемых фрагментов (https://www.ncbi.nlm.nih.gov/tools/primer-blast). Определяемые виды грибков рода Fusarium и рода Myrothecium, указанные в таблице, наиболее распространены в нашем регионе. Также методом nested-ПЦР в суммарной ДНК семян устойчивого к болезням сорта Куяльник определялись Penicillium spp., Aspergillus parasiticus и Alternaria alternata.

Реакция проводилась в 25 мкл, включающих 66 мМ Tris- $\mathrm{HCl}$ (pH 8.4), 16 мМ (NH4) $\mathrm{SO}_{4}, 2,5 \mathrm{mM} \mathrm{MgCl}, 0,1 \%$ Tween 20, 7 \% глицерол, 100 мкл-1 BSA, 0,2 mM каждого dNTP, 1,25 единиц Таq ДНК полимеразы (Thermo Fisher Scientific), 5 pM прямого и обратного праймеров и 10 нг ДНК.

Условия проведения полимеразной цепной реакции. Первый раунд: 3 мин денатурации при $95^{\circ} \mathrm{C}$, затем 30 циклов, включающих денатурацию $\left(1\right.$ мин, $\left.95^{\circ} \mathrm{C}\right)$, отжиг $\left(1\right.$ мин, $\left.60^{\circ} \mathrm{C}\right)$, элонгацию $\left(1 \mathrm{мин,}, 72^{\circ} \mathrm{C}\right)$, и 1 цикл финальной элонгации $(7 \mathrm{Mин,}$ $\left.72^{\circ} \mathrm{C}\right)$.Второй раунд: 30 циклов, включающих денатурацию $\left(1 \mathrm{мин,} 95^{\circ} \mathrm{C}\right)$, отжиг $(1 \mathrm{мин,}$ $\left.60^{\circ} \mathrm{C}\right)$, элонгацию $\left(1\right.$ мин, $\left.72^{\circ} \mathrm{C}\right)$, и 1 цикл финальной элонгации $\left(7\right.$ мин, $\left.72^{\circ} \mathrm{C}\right)$. Продукты амплификации были разделены с помощью гель-электрофореза в 1,5\% агарозном геле с добавлением бромистого этидия в конечной концентрации 5мкг/мл, использовался молекулярный маркер (М) фирмы Thermoscientific ( GeneRuler 100 bp DNA ) Визуализация проводилась в УФ свете при длине волны 302 нм.

\section{Результаты и обсуждения}

На рис 1. представлен электрофорез продуктов амплификации реакции nested-ПЦР с парами видоспецифичных праймеров к основным видам фузариума, наиболее 
распространенным в нашем регионе на посевах пшеницы (F. verticillioides, F. avenaceum, F. oxysporum, F. equiseti, F. sporotrichioides ).

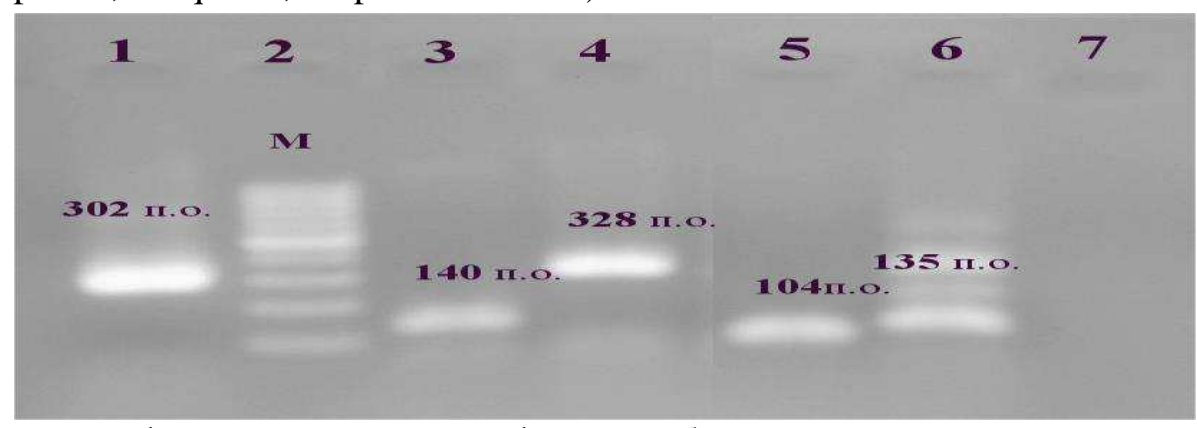

Рис.1.Электрофорез продуктов амплификации образцов ДНК, выделенной из зерна сортастандарта Куяльник. №1.-Fusarium verticillioides, №2- маркер, №3- Fusarium avenaceum,

№4- F. oxysporum,№5-F. equiseti, №6- F. sporotrichioides, №7-контроль (вода).

Образец №1 демонстрирует большое количество ДНК-матрицы F. verticillioides (согласно табл1. величина амплифицируемого фрагмента в этом случае 302 п.о.). В карман геля под номером 2 нанесен молекулярный маркер M (GeneRuler 100 bp DNA), позволяющий определять длину амплифицируемых фрагментов исследуемых образцов. Положительный сигнал на электрофорезе образца №3 говорит о наличии F. avenaceum в ДНК-матрице семян пшеницы сорта Куяльник (139 п.о. согласно табл.1).

Дорожка №4- содержит ампликоны размером 328 п.о., что соответствует длине амплифицируемого фрагмента с праймерами к F. oxysporum, №5- продукты реакции nested-ПЦР с праймерами к F. equiseti (104 п.о.), №6 -F. sporotrichioides ( 135 п.о.), №7контроль (вода). Методом ПЦР ( в 1 раунд, количество циклов 45) в следовых количествах был обнаружен Fusarium incarnatum в образцах ДНК, выделенных из семян озимой пшеницы сорта-стандарта Куяльник.

На рисунке 2 представлены результаты реакции nested-ПЦР с праймерами к следующим фитопатогенам: Penicillium spp., Alternaria alternata, Aspergillus parasiticus, Myrothecium roridum и M. verrucaria. Обнаружены следовые количества Penicillium spp. (дорожка №1- величина ампликона 249 п.о.). Яркий интенсивный сигнал образца №3 ( величина ампликона 288 п.о.) говорит о наличии большого количества ДНК-матрицы Alternaria alternata. Фитопатогены Aspergillus parasiticus (№4), Myrothecium roridum (№5) и М. verrucaria (№6) в образцах ДНК, выделенных из семян озимой пшеницы сорта Куяльник урожая 2019 года не обнаружены.

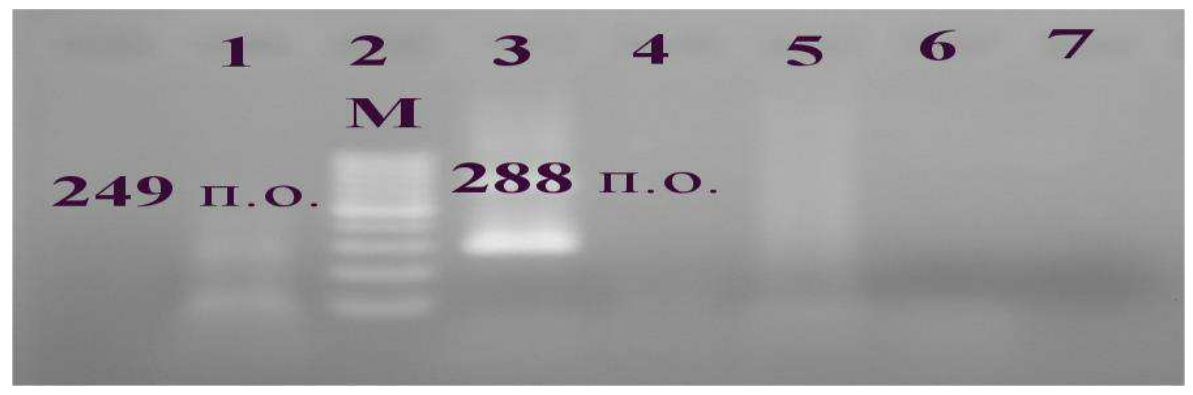

Рис.2. Электрофорез продуктов амплификации образцов ДНК, выделенной из зерна сортастандарта Куяльник. №1-Penicillium spp., №3- Alternaria alternata, №4- Aspergillus parasiticus, №5- Myrothecium roridum, №6- M. verrucaria, №7- контроль (вода). 


\section{Выводы}

Семена озимой пшеницы сорта Куяльник (стандарта продуктивности и устойчивости к болезням) содержат значительное количество вредоносных фитопатогенов $(F$. verticillioides, $F$. avenaceum, $F$. oxysporum, $F$. equiseti, $F$. sporotrichioides, F.incarnatum, Alternaria alternata, Penicillium spp.). Возбудители Myrothecium spp. и Aspergillus parasiticus не были обнаружены в семенах данного сорта урожая 2019 года. Широкий спектр фитопатогенов в семенах пшеницы делает необходимым предпосевное протравливание семян фунгицидами для поддержания фитосанитарного здоровья посевов и сортов.

\section{Библиография}

1. Николаева С., Маржина Л., Николаев А. Патогенные свойства грибов рода Myrothecium Tode ex Fries, Studia universitatis, 2010, nr.1(31), 88-93.

2. GenBank https://www.ncbi.nlm.nih.gov/genbank

3. ISO 21571:2005(en) Foodstuffs - Methods of analysis for the detection of genetically modified organisms and derived products - Nucleic acid extraction [Online]. URL: https://www.iso.org/obp/ui/\#iso:std:iso:21571:ed-1:v1:en
4. MycoBank Database http://www.mycobank.org 